\title{
Studies on the impact and efficiency of integrated nutrient management on yield, major and secondary nutrient content of okra crop for sustainable agriculture
}

\author{
A. DHAVAPPRIYA*, V. SANJIVKUMAR AND S.T. KUMARAN ${ }^{1}$ \\ Department of Soil Science and Agricultural Chemistry, Tamil Nadu Agricultural University, COIMBATORE \\ (T.N.) INDIA (Email : dhavappriya @gmail.com)
}

\begin{abstract}
Combined use of animal wastes is necessary in order to obtain adequate amount of organic manure for use in crop production. Hence, field experiment was conducted in Agricultural College and Research Institute, Tamil Nadu Agricultural University, Madurai to evaluate the response of okra (Arka anamika) with organic sources like goat manure and pig manure combined with inorganic fertilizers on yield, major and secondary nutrient content. There were ten treatment combinations replicated thrice in Randomized Block Design (RBD) in Maddukkur soil

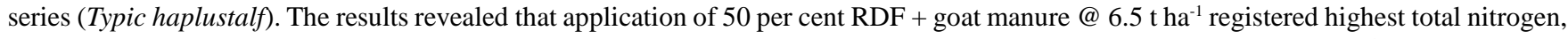
phosphorus, potassium, calcium and magnesium content and yield $\left(1.71 \%, 0.44 \%, 1.58 \%, 1.36 \%\right.$ and $0.68 \%$ and $13.0 \mathrm{t}$ ha $\left.{ }^{-1}\right)$. The least value recorded in the untreated control $(1.30 \%, 0.20 \%, 1.22 \%, 1.10 \%$ and $0.35 \%)$ and $11.90 \mathrm{t} \mathrm{ha}^{-1}$, respectively.
\end{abstract}

Key Words : Animal manures, Okra, Total major, Secondary nutrients, Yield

View Point Article : Dhavappriya, A., Sanjivkumar, V. and Kumaran, S.T. (2015). Studies on the impact and efficiency of integrated nutrient management on yield, major and secondary nutrient content of okra crop for sustainable agriculture. Internat. J. agric. Sci., 11 (1): $63-67$.

Article History : Received : 26.05.2014; Revised : 07.11.2014; Accepted : 24.11.2014

\footnotetext{
* Author for correspondence

${ }^{1}$ Department Agronomy, Tamil Nadu Agricultural University, COIMBATORE (T.N.) INDIA
} 